\title{
Toll-like receptors 3 ligation directly and indirectly affects mast cell cysteinyl leukotriene generation
}

\author{
PIOTR WITCZAK, ANNA PIETRZAK, ALEKSANDRA SŁODKA, EWA BRZEZIŃSKA-BEASZCZYK
}

Department of Experimental Immunology, Medical University of Lodz, Lodz, Poland

\begin{abstract}
Mast cells are numerously distributed throughout the body, but are particularly abundant beneath subepithelial layers of the skin, in the airways, gastrointestinal and genitourinary tracts, thus close to the external environment, virtually at the portals of infection. These cells express Toll-like receptors (TLRs) that detect bacteria-associated specific molecules. There are sparse data that mast cells have intracellular TLRs, such as TLR3, TLR7/8, and TLR9, recognizing virus-derived molecules. Thus, the aim of our study was to determine whether TLR3 ligand activates mast cells to degranulation and preformed mediator release as well as to cysteinyl leukotriene (cysLT) generation. The indirect effect of TLR3 ligation on IgE-mediated mast cell response was also examined. Experiments were carried out in vitro on isolated mature rat peritoneal mast cells and poly(I:C), a synthetic mimic of viral double-stranded (ds)RNA - TLR3 ligand, was used. Toll-like receptor 3 protein expression was assessed by western blot method. Poly(I:C)-induced mast cell degranulation was evaluated by histamine release by spectrofluorometric method, and cysLT generation and release was estimated by the ELISA test. We documented that native rat peritoneal mast cells constitutively express TLR3 protein. We also found that mast cells do not release histamine but generate and secrete cysLTs upon direct poly(I:C) stimulation. Mast cell priming with poly(I:C) has no effect on anti-IgE-induced histamine release. However, mast cell costimulation with poly(I:C) and anti-IgE causes a significant amplification of cysLT secretion. Our results suggest that dsRNA viruses could activate mast cells to proinflammatory mediator release and might affect severity of IgE-mediated allergic reactions.
\end{abstract}

Key words: mast cells, Toll-like receptors, anti-viral response, cysteinyl leukotrienes.

(Centr Eur J Immunol 2013; 38 (3): 343-348)

\section{Introduction}

Mast cells are long-lived resident tissue cells numerously distributed throughout the body. These cells are a significant source of diverse mediators such as granule-associated preformed mediators (e.g. histamine, proteases, proteoglycans, metalloproteinases), de novo generated and secreted arachidonic acid metabolites [i.e. leukotrienes (LTs), prostaglandins (PGs) and thromboxanes (TXs)] as well as cytokines and chemokines [1,2]. These mediators elicit pro-inflammatory, anti-inflammatory and immunoregulatory effects and act directly on various cell populations. Therefore, mast cells are important players in homeostasis maintenance via involvement in angiogenesis, tissue remodeling and repair, and regulation of vascular permeability [2-4].
These cells are also known to participate in the inflammatory processes [4-6]. Moreover, mast cells also take part in different pathological processes $[3,7,8]$, including FceRImediated allergic reactions [6, 8-10].

Mast cells are particularly abundant beneath subepithelial layers of the skin, in the airways, gastrointestinal and genitourinary tracts, thus close to the external environment, virtually at the portals of infection $[1,2]$. Furthermore, these cells express pathogen recognition receptors (PRRs), including Toll-like receptors (TLRs) [11], that detect bacteria-associated specific molecules [12]. Therefore, mast cells are considered to be engaged in both innate and adaptive immune response against bacteria [13-15]. More recently the question arose as to whether mast cells

Correspondence: Ewa Brzezińska-Błaszczyk, Department of Experimental Immunology, Medical University of Lodz, Pomorska 251, 92-213 Lodz, Poland, tel./fax +48 4267573 06, e-mail: ewab@csk.umed.lodz.pl 
have similar structures to detect virus-derived components. Among the TLR family members, TLR3, TLR7/8 and TLR9 are the receptors specific to virus-associated molecular patterns [11, 16]. Although previously these receptors have been reported in mast cells, the data are scarce and mainly refer to mRNA transcript expression in cultured cell lines [17-22]. Thus, it could be assumed that mast cells are capable of being activated by viral ligands, and thereby involved in antiviral immune response and/or development of virus-induced diseases. Toll-like receptor 3 is regarded as the predominant receptor of cellular response to viral infections, because it detects a frequent by-product of viral replication, namely double-stranded (ds)RNA [23]. Therefore, the aim of our study was to determine whether polyinosinic-polycytidylic acid (poly(I:C)), TLR3-specific synthetic analogue of viral dsRNA, can directly activate mature mast cells to degranulation as well as generation of cysteinyl LTs (cysLTs), the key mediator of inflammation [23, 24]. Due to mast cells' essential role in allergic reactions [6, 8-10], we also examined the effect of TLR3 ligation on FceRI-mediated mast cell response.

\section{Material and methods}

\section{Isolation of mast cells}

Mast cells were collected from peritoneal cavities by lavage with $50 \mathrm{ml}$ of $1 \%$ Hank's Balanced Salt Solution (HBSS) supplemented with $0.015 \% \mathrm{NaHCO}_{3}$ (Life Technologies, Gaithersburg, MD, USA). Next, the abdominal massage ( $90 \mathrm{~s}$ ) was performed and the cell suspension was removed from the peritoneal cavity, centrifuged $(150 \mathrm{~g}$, $5 \mathrm{~min}, 20^{\circ} \mathrm{C}$ ), and washed twice in complete Dulbecco's Modified Eagle Medium (cDMEM) containing DMEM supplemented with $10 \%$ fetal calf serum (FCS), $10 \mu \mathrm{g} / \mathrm{ml}$ gentamicin and $2 \mathrm{mM}$ glutamine $\left(150 \mathrm{~g}, 5 \mathrm{~min}, 20^{\circ} \mathrm{C}\right)$ (Life Technologies). In order to prepare purified mast cells, the isotonic $72.5 \%$ Percoll (Sigma-Aldrich Co. St. Louis, MO, USA) density gradient centrifugation $\left(190 \mathrm{~g}, 15 \mathrm{~min}, 20^{\circ} \mathrm{C}\right)$ was used and the cells were washed twice in cDMEM by centrifugation $\left(150 \mathrm{~g}, 5 \mathrm{~min}, 20^{\circ} \mathrm{C}\right)$. Subsequently, the cells were counted and resuspended in the appropriate volume of medium for rat mast cells containing $1 \mathrm{mM} \mathrm{MgCl}_{2}, 2.7 \mathrm{mM} \mathrm{KCL}$, $137 \mathrm{mM} \mathrm{NaCl}, 1 \mathrm{mM} \mathrm{CaCl}_{2}, 10 \mathrm{mM} \mathrm{N}$-2-hydroxyethylpiperazine-N'-ethanesulphonic acid (HEPES) buffer, $5.6 \mathrm{mM}$ glucose and $1 \mathrm{mg} / \mathrm{ml}$ bovine serum albumin (BSA) (SigmaAldrich) (the $\mathrm{pH}$ of the medium was adjusted to 6.9) to obtain mast cell concentration of $1.5 \times 10^{6}$ cells $/ \mathrm{ml}$. Mast cells were prepared with purity over $98 \%$, as determined by metachromatic staining with toluidine blue (Sigma-Aldrich).

\section{Western blot analysis}

Mast cells were lysed in ice-cold radioimmunoprecipitation assay (RIPA) buffer [50 mM Tris-HCl, pH 8.0, with 150 $\mathrm{mM} \mathrm{NaCl}, 1 \%$ Igepal CA-630 (NP-40), $0.5 \%$ sodium deoxycholate, and $0.1 \%$ sodium dodecyl sulfate (SDS) (InvivoGen,
San Diego, CA, USA)] containing protease inhibitor cocktail [1 mM 4-(2-Aminoethyl) benzenesulfonyl fluoride hydrochloride (AEBSF), $800 \mathrm{nM}$ aprotinin, $50 \mu \mathrm{M}$ bestatin, $15 \mu \mathrm{M}$ E64, $20 \mu \mathrm{M}$ leupeptin, $10 \mu \mathrm{M}$ pepstatin A, $5 \mathrm{mM}$ ethylenediaminetetraacetic acid (EDTA)] (Thermo Scientific, Rockford, IL, USA) for 30 min on ice and detergent-insoluble residues were removed. The protein concentration in the lysates was determined by Bradford Assay (Bio-Rad Laboratories, Inc., United States). The cell lysates $(50 \mu \mathrm{g})$ were separated on NuPAGE 10\% Bis-Tris Gel (Life Technologies) before transfer to polyvinylidene difluoride (PVDF) membrane (Millipore, Billerica, MA, USA). The expression of TLR3 was assessed using anti-TLR3 antibodies (1 : 200 dilution), followed by application of horseradish peroxidase-conjugated bovine anti-goat IgG (1:10 000 dilution) (Santa Cruz Biotechnology, Santa Cruz, CA, USA). The specific protein was visualized by the enhanced chemiluminescence (ECL) system using ECL Chemiluminescent Substrate Reagent Kit (Life Technologies) according to manufacturer's instructions.

\section{Histamine release assay}

The purified mast cells were suspended in the medium and divided into $90 \mu \mathrm{l}$ aliquots. Next, $10 \mu \mathrm{l}$ of poly(I:C) (InvivoGen, San Diego, CA, USA) at final concentrations of $0.1 \mu \mathrm{g} / \mathrm{ml}$ or $100 \mu \mathrm{g} / \mathrm{ml}$, compound 48/80 (SigmaAldrich) at final concentration of $5 \mu \mathrm{g} / \mathrm{ml}$ (positive control) or medium alone (negative control) was added and incubation in water bath with constant stirring was performed for $1 \mathrm{~h}$ or $1.5 \mathrm{~h}$ at $37^{\circ} \mathrm{C}$. Then, $1.9 \mathrm{ml}$ of cold medium was added to stop the reaction. The cell suspensions were centrifuged $\left(150 \mathrm{~g}, 5 \mathrm{~min}, 4^{\circ} \mathrm{C}\right)$ and the supernatants were decanted into separate tubes and acidified with $3 \mathrm{~N} \mathrm{HCl}$. Subsequently, distilled water at a total volume of $2 \mathrm{ml}$ was added to each tube containing cell pellet. The histamine content was assessed in cell pellets (residual histamine) as well as supernatants (released histamine) by a spectrofluorometric method using o-phthaldialdehyde (OPT) (SigmaAldrich). Histamine release was expressed as a percentage of the total cellular content of the amine.

In another series of experiments mast cells were preincubated with poly(I:C) at final concentrations of $0.1 \mu \mathrm{g} / \mathrm{ml}$ or $100 \mu \mathrm{g} / \mathrm{ml}$, or medium alone for $1 \mathrm{~h}$ at $37^{\circ} \mathrm{C}$. After washing, mast cells were challenged with anti-IgE (Serotec, Oxford, UK) at final concentration of $5 \mu \mathrm{g} / \mathrm{ml}$ or medium alone (negative control) for $30 \mathrm{~min}$ at $37^{\circ} \mathrm{C}$. The reaction was stopped with the cold medium and histamine content was assessed, as described above.

\section{CysLT release assay}

The purified mast cells suspended in the medium were incubated with poly(I:C) at final concentrations of $0.1 \mu \mathrm{g} / \mathrm{ml}$ or $100 \mu \mathrm{g} / \mathrm{ml}$, calcium ionophore A23187 (Sigma-Aldrich) at final concentration of $5 \mu \mathrm{g} / \mathrm{ml}$ (positive control) or medium alone (negative control) for $2 \mathrm{~h}$ or $3 \mathrm{~h}$ at $37^{\circ} \mathrm{C}$. The supernatants were collected by centrifugation $(150 \mathrm{~g}, 5 \mathrm{~min}$, 
$20^{\circ} \mathrm{C}$ ) and analyzed by an ELISA commercial kit (Cayman Chemical, Ann Arbor, MI, USA) detecting LTC $_{4}$ and its degradation products $\mathrm{LTD}_{4}$ and $\mathrm{LTE}_{4}$. The sensitivity of this assay was $<13 \mathrm{pg} / \mathrm{ml}$.

To determine the specificity of poly(I:C) effect on cysLT bated with goat polyclonal anti-TLR3 IgG antibodies or goat IgG isotype control (Santa Cruz Biotechnology) at final concentration of $40 \mu \mathrm{g} / \mathrm{ml}$ or medium alone (negative control) for $1 \mathrm{~h}$ at $37^{\circ} \mathrm{C}$. Next, the cells were rinsed twice by centrifugation at $150 \mathrm{~g}$ for $5 \mathrm{~min}$ and resuspended in the medium before poly(I:C) stimulation, as described.

In separate experiments, mast cells were incubated with anti-IgE at final concentration of $5 \mu \mathrm{g} / \mathrm{ml}$, poly(I:C) at final concentrations of $0.1 \mu \mathrm{g} / \mathrm{ml}$ or $100 \mu \mathrm{g} / \mathrm{ml}$, both poly(I:C) and anti-IgE, or medium alone (negative control) for $2 \mathrm{~h}$ at $37^{\circ} \mathrm{C}$. The supernatants were collected by centrifugation and analysed for cysLTs, as described.

\section{Statistical analysis}

Statistical analysis included mean value, standard error of the mean (SEM) and Student's $t$-test for "small groups". Values of $P<0.05$ were considered statistically significant.

\section{Results}

\section{Mast cell TLR3 expression}

To our knowledge, TLR3 protein has not been yet determined in mature tissue rat mast cells. Therefore, we examined these cells for TLR3 molecule expression. The westgeneration in some experiments mast cells were preincu-

$\mathrm{kDa}$
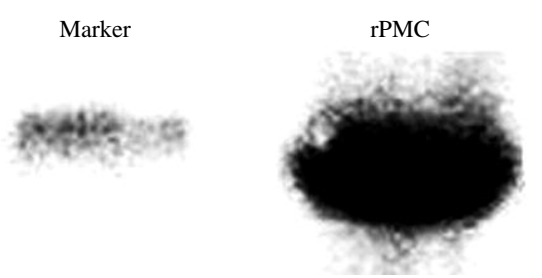

Fig. 1. TLR3 protein expression in rat peritoneal mast cells (rPMCs) assessed by Western blotting

ern blot analysis revealed distinct $120 \mathrm{kDa}$ band corresponding to TLR3 protein (Fig. 1). Thereby, we demonstrated that freshly isolated rat peritoneal mast cells constitutively express TLR3 protein.

\section{Direct effect of poly(I:C) on mast cell histamine release and cysLT synthesis}

First, the effect of TLR3 ligand, i.e. poly(I:C), on mast cells degranulation and preformed mediator release was investigated. We observed that poly(I:C), used at two different concentrations, did not induce mast cell degranulation and histamine secretion (Fig. 2A). In comparison, upon stimulation with compound $48 / 80$, a potent trigger of mast cell degranulation, histamine release was up to $60.1 \pm 2.1 \%$ (mean $\pm \mathrm{SEM}$ ) after $1.5 \mathrm{~h}$ of incubation.

We found, however, that poly(I:C) activated rat mast cells to cysLT generation and release (Fig. 2B). Poly(I:C) at concentration of $0.1 \mu \mathrm{g} / \mathrm{ml}$ stimulated mast cells to release up to $150.6 \pm 18.5$ and up to $344.2 \pm 35.4 \mathrm{pg}$ cysLT/1.5 $\times 10^{6}$ mast cells after $2 \mathrm{~h}$ and $3 \mathrm{~h}$ of incubation, respectively. CysLT release from mast cells in response to activation with

B

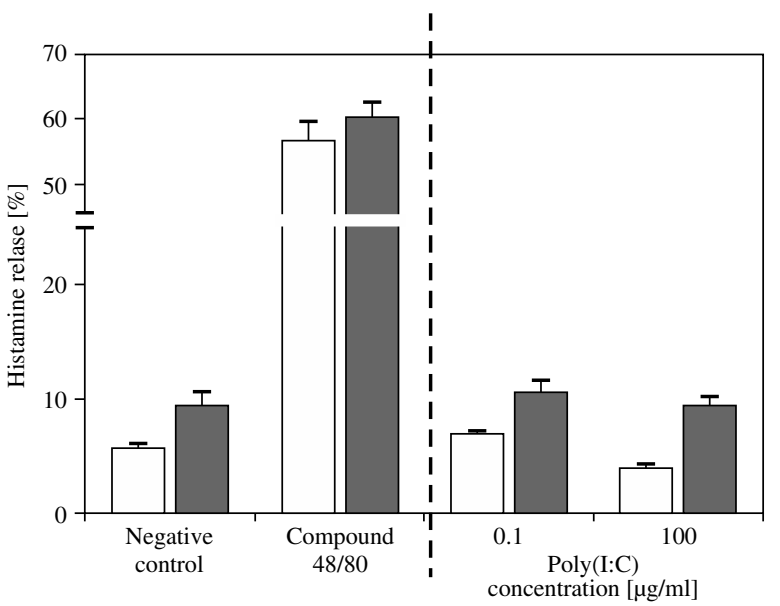

Fig. 2. Direct effect of TLR3 ligand, i.e. poly(I:C), on mast cell (A) histamine release and (B) cysLT synthesis. (A) Mast cells were incubated with poly(I:C), compound 48/80 (positive control) or medium alone (negative control) for $1 \mathrm{~h}$ (white bars) or $1.5 \mathrm{~h}$ (dark bars). (B) Mast cells were incubated with poly(I:C), calcium ionophore A23187 (positive control) or medium alone (negative control) for $2 \mathrm{~h}$ (white bars) or $3 \mathrm{~h}$ (dark bars), or pretreated with anti-TLR3 or isotype control antibodies for $1 \mathrm{~h}$ prior to poly(I:C) exposure. Results are the mean \pm SEM of three independent experiments and each experiment was done in duplicate $(n=6) . * * * P<0.001$ 
poly(I:C) used at $100 \mu \mathrm{g} / \mathrm{ml}$ was $202.0 \pm 19.7 \mathrm{pg} / 1.5 \times 10^{6}$ mast cells (time of stimulation $-2 \mathrm{~h}$ ) and $392.5 \pm 27.7 \mathrm{pg} / 1.5$ $\times 10^{6}$ mast cells (time of stimulation $-3 \mathrm{~h}$ ). In comparison, when challenged with calcium ionophore A23187 under the same experimental conditions, mast cells released up to $921.1 \pm 20.1 \mathrm{pg} / 1.5 \times 10^{6}$ mast cells ( $2 \mathrm{~h}$-incubation) and $949.8 \pm 17.0 \mathrm{pg} / 1.5 \times 10^{6}$ mast cells ( $3 \mathrm{~h}$-incubation) of cysLTs.

To determine the specificity of poly(I:C) action on mast cell cysLT generation and release, blocking experiments using anti-TLR3 antibodies were performed. We noticed that pretreatment of mast cells with these antibodies almost completely inhibited cysLT synthesis in response to poly(I:C) exposure. The isotype control antibodies did not affect poly(I:C)-induced cysLT generation by mast cells (Fig. 2B).

\section{Effect of poly(I:C) on mast cell anti-IgE-mediated histamine release and cysLT synthesis}

Next, the influence of poly(I:C) on mast cell anti-IgEmediated degranulation and preformed mediator release was evaluated. As shown in Fig. 3A, pretreatment of mast cells with poly(I:C), used at concentrations of $0.1 \mu \mathrm{g} / \mathrm{ml}$ and $100 \mu \mathrm{g} / \mathrm{ml}$ for $1 \mathrm{~h}$, did not affect histamine release induced by anti-IgE. On the contrary, we found that co-stimulation of mast cells with TLR3 ligand at concentration of $100 \mu \mathrm{g} / \mathrm{ml}$ and anti-IgE for $2 \mathrm{~h}$ resulted in a significant amplification of cysLT secretion $\left(473.5 \pm 18.4 \mathrm{pg} / 1.5 \times 10^{6}\right.$ mast cells, compared to $265.2 \pm 11.9 \mathrm{pg} / 1.5 \times 10^{6}$ mast cells for TLR3 ligand untreated cells) (Fig. 3B). However, simultaneous treatment of mast cells with poly(I:C) at concen-

A

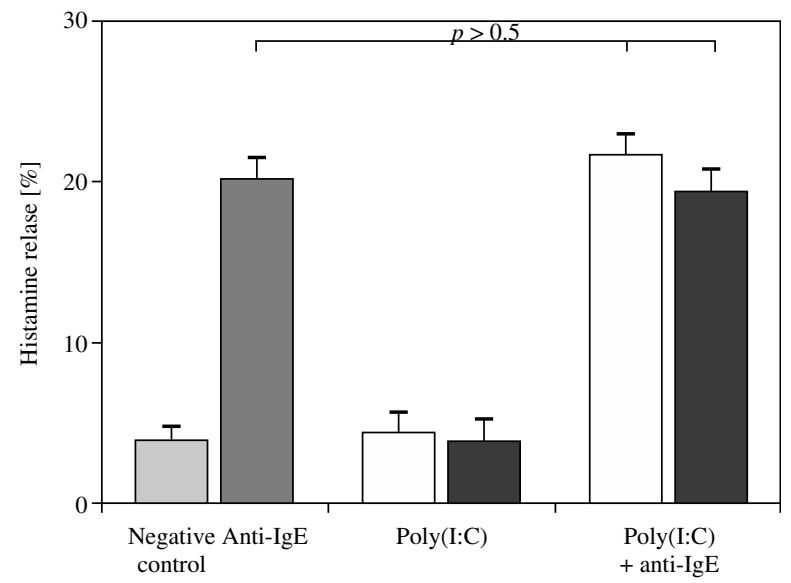

tration of $0.1 \mu \mathrm{g} / \mathrm{ml}$ and anti-IgE had no significant co-stimulatory effect on cysLT synthesis.

\section{Discussion}

So far, TLR3 mRNA has been found in human and murine immature mast cells $[17,19,21,26]$ as well as in mature human mast cells isolated from skin and lungs [27] and mouse mast cells obtained from fetal skin (FSMCs) [18]. Toll-like receptor 3 protein has been shown to be present in human and murine mast cell lines [17, 19, 21]. To our knowledge, only Kulka et al. [17] documented TLR3 at the protein level in mature native murine mast cells. In this study, we proved that mature connective tissue mast cells from rat peritoneal cavity constitutively express TLR 3 protein. All these data indicate that mast cells could sense and respond to dsRNA viruses.

We also found that poly(I:C), a synthetic mimic of viral dsRNA, does not induce rat mature mast cells to degranulation and preformed mediator release. However, mast cells released cysLTs upon exposure to TLR3 ligand, though the amount of secreted mediators was relatively small. Nevertheless, it should be underlined that cysLTs are extremely potent proinflammatory mediators which produce their effects even at nanomolar concentrations [24, 25, 28]. Earlier studies showed that poly(I:C) does not activate immature bone marrow-derived mast cells (BMMCs) as well as mature FSMCs, human cutaneous and pulmonary mast cells and murine peritoneal mast cells to degranulation, as assessed by levels of $\beta$-hexosaminidase release [18, 19, 27]. Saluja et al. [26] observed no degranulation and cysLT gen-

\section{B}

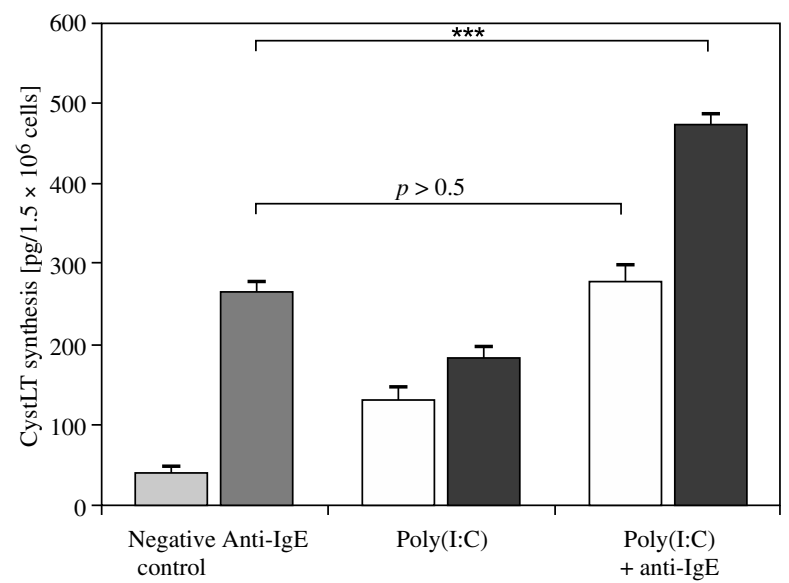

Fig. 3. Indirect effect of TLR3 ligand, i.e. poly(I:C), on mast cell IgE-mediated (A) histamine release and (B) cysLT synthesis. (A) Mast cells were pretreated with poly(I:C) at concentrations of $0.1 \mu \mathrm{g} / \mathrm{ml}$ (white bars) or $100 \mu \mathrm{g} / \mathrm{ml}$ (black bars) or medium alone for $1 \mathrm{~h}$ and then incubated with anti-IgE or medium (negative control) for $30 \mathrm{~min}$. (B) Mast cells were incubated with poly(I:C) at concentrations of $0.1 \mu \mathrm{g} / \mathrm{ml}$ (white bars) or $100 \mu \mathrm{g} / \mathrm{ml}$ (black bars), anti-IgE, medium alone (negative control), or both poly(I:C) and anti-IgE for $2 \mathrm{~h}$. Results are expressed as the mean $\pm \mathrm{SEM}$ of three separate experiments and each experiment was done in duplicate $(n=6)$. $* * P<0.01$, *** $P<0.001$ 
eration by mouse in vitro-differentiated connective tissuelike mast cells (CTLMCs) and mucosal-like mast cells (MLMCs) in response to poly(I:C) stimulation. Burke et al. [29] stated that poly(I:C)-activated human cord bloodderived mast cells (CBMCs) do not produce cysLTs. To date, only Kulka et al. [17] demonstrated selective, i.e. without degranulation, poly(I:C)-induced cysLT production by human cultured mast cells (HCMCs).

There are some observations that murine and human mast cells are capable of responding to TLR3 stimulation by producing type I interferons (IFNs) [17], key factors for the induction of antiviral defense. What is more, poly(I:C)-activated mast cells produce and secrete proinflammatory cytokines, such as tumor necrosis factor (TNF) and interleukin (IL)-6 [18, 21]. Furthermore, mast cell activation via TLR3 ligation results in selective synthesis and release of several chemokines, including CCL2, CCL3, CCL4, CCL5, CXCL1, CXCL2, CXCL8, and CXCL10 [18, 19, 21, 26, 29]. Mast cell-derived proinflammatory cytokines as well as chemokines strongly influence the development of antiviral immune response and act as NK and cytotoxic CD8+ T cell chemoattractants. It might be suggested that cysLTs generated by mast cells in response to TLR3 ligation intensify inflammatory processes by enhancing vascular permeability thereby affecting cellular migration during virus infection.

It is well documented that viral infections induce exacerbations of bronchial asthma [30-32], but the underlying mechanisms remain unclear. Thus, we studied the influence of TLR3 ligation on FceRI-mediated mature rat mast cell degranulation and cysLT generation. We documented that mast cell priming with TLR3 ligand for $1 \mathrm{~h}$ had no effect on anti-IgE-induced degranulation. However, mast cell costimulation with poly(I:C), but only at the higher concentration used, and anti-IgE for $2 \mathrm{~h}$ caused significant augmentation in cysLT generation. It might be speculated that high concentrations of poly(I:C) may up-regulate FceRI expression and thereby increase IgE-dependent cysLT release. Previously, it was observed that poly(I:C) pretreatment for 5-12 h had no effect on IgE-mediated degranulation of HCMCs and LAD cells [17] and priming with TLR3 ligand, up to $24 \mathrm{~h}$, did not affect FceRI-dependent $\beta$-hexosaminidase release as well as cysLT and $\mathrm{LTB}_{4}$ generation by CTLMCs and MLMCs derived from cultured mouse bone marrow cells [26]. However, the prolonged, up to $96 \mathrm{~h}$, exposure to TLR3 ligand caused a significant increase in CTLMs and MLMCs degranulation and induced an amplified secretion of cysLTs from CTLMCs [26]. The observations that mast cell activation by dsRNA can induce augmentation of cysLT generation in response to FceRImediated stimulation seem to be of great importance. It is a commonly held belief that cysLTs play an important role in the pathogenesis of acute and chronic asthma. These mediators display a variety of disorder-provoking physiological effects such as increased microvascular permeability leading to pulmonary edema, impaired ciliary activity responsible for enhanced mucus secretion and decreased respiratory self-clearance, as well as respiratory tract smooth muscle cell hyperplasia contributing to airway remodeling [33]. CysLTs are also known to be essential in the course of allergic rhinitis [34].

In conclusion, we clearly demonstrated that native mature tissue mast cells constitutively express TLR3 molecule and can be activated via poly(I:C), a synthetic dsRNA construct, to cysLT generation and release. These observations might suggest that mast cells can be directly activated to proinflammatory mediator release during dsRNA virus infections. Furthermore, data showing that priming/co-stimulation with TLR3 ligand may affect FceRIdependent mast cell activation indicate that dsRNA virus infections could influence allergic reaction severity. However, to clarify the impact of TLR3 ligation on mast cell reactivity, further studies are necessary.

\section{The authors declare no conflict of interests.}

This work was supported by the National Science Centre in Poland (Grant No. 2011/03/N/NZ6/03528) and by the Medical University of Łódź (Grant No. 502-03/6-16401/502-64-005).

\section{References}

1. Gilfillan AM, Austin SJ, Metcalfe DD (2001): Mast cell biology: introduction and overview. Adv Exp Med Biol 716: 2-12.

2. Rao KN, Brown MA (2008): Mast cells: multifaceted immune cells with diverse roles in health and disease. Ann N Y Acad Sci 1143: 83-104.

3. Heib V, Becker M, Taube C, Stassen M (2008): Advances in the understanding of mast cell function. Br J Haematol 142: 683-694.

4. Galli SJ, Tsai M (2008): Mast cells: versatile regulators of inflammation, tissue remodeling, host defense and homeostasis. J Dermatol Sci 49: 7-19.

5. Crivellato E, Ribatti D (2005): Involvement of mast cells in angiogenesis and chronic inflammation. Curr Drug Targets Inflamm Allergy 4: 9-11.

6. Theoharides TC, Kalogeromitros D (2006): The critical role of mast cells in allergy and inflammation. Ann N Y Acad Sci 1088: 78-99.

7. Weller CL, Collington SJ, Williams T, Lamb JR (2011): Mast cells in health and disease. Clin Sci 120: 473-484.

8. Anand P, Singh B, Jaggi AS, Singh N (2012): Mast cells: an expanding pathophysiological role from allergy to other disorders. Naunyn Schmiedebergs Arch Pharmacol 385: 657-670.

9. Brown JM, Wilson TM, Metcalfe DD (2008): The mast cell and allergic diseases: role in pathogenesis and implications for therapy. Clin Exp Allergy 1: 4-18.

10. Stelekati E, Orinska Z, Bulfone-Paus S (2007): Mast cells in allergy: innate instructors of adaptive responses. Immunobiol 6: 505-519.

11. Brzezińska-Błaszczyk E, Wierzbicki M (2010): Mast cell Tolllike receptors (TLRs). Postepy Hig Med Dosw 64: 11-21.

12. Takeda K, Akira S (2004): Microbial recognition by Toll-like receptors. J Dermatol Sci 34: 73-82. 
13. Marshall JS (2004): Mast-cell responses to pathogens. Nat Rev Immunol 4: 787-799.

14. Abraham SN, St John AL (2010): Mast cell-orchestrated immunity to pathogens. Nat Rev Immunol 10: 440-452.

15. Tete S, Tripodi D, Rosati M, et al. (2012): Role of mast cells in innate and adaptive immunity. J Biol Regul Homeost Agents 26: 193-201.

16. Blasius AL, Beutler B (2010): Intracellular toll-like receptors. Immunity 32: 305-315.

17. Kulka M, Alexopoulou L, Flavell RA, Metcalfe DD (2004): Activation of mast cells by double-stranded RNA: evidence for activation through Toll-like receptor 3. J Allergy Clin Immunol 114: 174-182.

18. Matsushima H, Yamada N, Matsue H, Shimada S (2004): TLR3-, TLR7-, and TLR9-mediated production of proinflammatory cytokines and chemokines from murine connective tissue type skin-derived mast cells but not from bone marrowderived mast cells. J Immunol 173: 531-541.

19. Orinska Z, Bulanova E, Budagian V, et al. (2005): TLR3induced activation of mast cells modulates CD8+ T-cell recruitment. Blood 106: 978-987.

20. Sundstrom JB, Little DM, Villinger F, et al. (2004): Signaling through Toll-like receptors triggers HIV-1 replication in latently infected mast cells. J Immunol 172: 4391-4401.

21. Yang H, Wei J, Zhang H, et al. (2009): Upregulation of Tolllike receptor (TLR) expression and release of cytokines from P815 mast cells by GM-CSF. BMC Cell Biol 10: 37 .

22. Yoshioka M, Fukuishi N, Iriguchi S, et al. (2007): Lipoteichoic acid downregulates Fc?RI expression on human mast cells through Toll-like receptor 2. J Allergy Clin Immunol 120: 452-461.

23. Sen GC, Sarkar SN (2005): Transcriptional signaling by double-stranded RNA: role of TLR3. Cytokine Growth Factor Rev 16: 1-14.

24. Singh RK, Gupta S, Dastidar S, Ray A (2010): Cysteinyl leukotrienes and their receptors: molecular and functional characteristics. Pharmacology 85: 336-349.

25. Peters-Golden M, Henderson WR Jr. (2007): Leukotrienes. N Engl J Med 357: 1841-1854.

26. Saluja R, Delin I, Nilsson GP, Adner M (2012): FceRI-mediated mast cell reactivity is amplified through prolonged Tolllike receptor-ligand treatment. PLoS One 7: e43547.

27. Kulka M, Metcalfe DD (2006): TLR3 activation inhibits human mast cell attachment to fibronectin and vitronectin. Mol Immunol 43: 1579-1586.

28. Arm JP (2004): Leukotriene generation and clinical implications. Allergy Asthma Proc 25: 37-42.

29. Burke SM, Issekutz TB, Mohan K, et al. (2008): Human mast cell activation with virus-associated stimuli leads to the selective chemotaxis of natural killer cells by a CXCL8-dependent mechanism. Blood 111: 5467-5476.

30. Busse WW, Lemanske RF Jr, Gern JE (2010): Role of viral respiratory infections in asthma and asthma exacerbations. Lancet 376: 826-834.

31. Dulek DE, Peebles RS Jr. (2011): Viruses and asthma. Biochim Biophys Acta 11: 1080-1090.

32. Kloepfer KM, Gern JE (2010): Virus/allergen interactions and exacerbations of asthma. Immunol Allergy Clin North Am 30: 553-563.

33. Holgate ST, Peters-Golden M, Panettieri RA, Henderson WR Jr. (2003): Roles of cysteinyl leukotrienes in airway inflammation, smooth muscle function, and remodeling. J Allergy Clin Immunol 111: S18-34.
34. Peters-Golden M, Henderson WR Jr. (2005): The role of leukotrienes in allergic rhinitis. Ann Allergy Asthma Immunol 94: 609-618. 